\title{
Ammonium Utilization in Microalgae: A Sustainable Method for Wastewater Treatment
}

\author{
Giovanna Salbitani *(D) and Simona Carfagna
}

Dipartimento di Biologia, Università di Napoli Federico II, Via Cinthia 21, 80126 Napoli, Italy; simcarfa@unina.it * Correspondence: giovanna.salbitani@unina.it

\begin{abstract}
In plant cells, ammonium is considered the most convenient nitrogen source for cell metabolism. However, despite ammonium being the preferred $\mathrm{N}$ form for microalgae, at higher concentrations, it can be toxic, and can cause growth inhibition. Microalgae's tolerance to ammonium depends on the species, with various taxa showing different thresholds of tolerability and symptoms of toxicity. In the environment, ammonium at high concentrations represents a dangerous pollutant. It can affect water quality, causing numerous environmental problems, including eutrophication of downstream waters. For this reason, it is important to treat wastewater and remove nutrients before discharging it into rivers, lakes, or seas. A valid and sustainable alternative to conventional treatments could be provided by microalgae, coupling the nutrient removal from wastewater with the production of valuable biomass. This review is focused on ammonium and its importance in algal nutrition, but also on its problematic presence in aquatic systems such as wastewaters. The aim of this work is to provide recent information on the exploitation of microalgae in ammonium removal and the role of ammonium in microalgae metabolism.
\end{abstract}

Keywords: ammonia; ammonium assimilation; extremophiles; microalgae; wastewater

Citation: Salbitani, G.; Carfagna, S. Ammonium Utilization in Microalgae: A Sustainable Method for Wastewater Treatment. Sustainability 2021, 13, 956. https://doi.org/10.3390/su13020956

Received: 9 December 2020

Accepted: 11 January 2021

Published: 19 January 2021

Publisher's Note: MDPI stays neutral with regard to jurisdictional claims in published maps and institutional affiliations.

Copyright: (c) 2021 by the authors. Licensee MDPI, Basel, Switzerland. This article is an open access article distributed under the terms and conditions of the Creative Commons Attribution (CC BY) license (https:// creativecommons.org/licenses/by/ $4.0 /)$.

\section{Introduction}

Microalgae are single-cell photosynthetic organisms, ranging in size from a few $\mu \mathrm{m}$ to a few hundred $\mu \mathrm{m}$; they are considered the greatest primary producer of any aquatic ecosystem. Although over 300,000 microalgal species exist, only around 30,000 have been studied or documented [1]. Phylogenetically, microalgae include many different groups, existing in various aquatic and terrestrial habitats, and are tolerant of a wide range of temperatures, salinities, $\mathrm{pH}$ values, and different light intensities. Therefore, they represent a huge group of organisms that can live in an extensive range of environments.

Recently, microalgae have attracted considerable interest worldwide due to their potential extensive applications in the renewable energy, biopharmaceutical, and nutraceutical industries [2,3]. A wide spectrum of biologically active compounds has been found in algal biomass; for example, proteins, polyunsaturated fatty acids (PUFAs), pigments, vitamins and minerals, and extracellular compounds such as oligosaccharides [4-7]. In particular, microalgae accumulate a high lipid content, normally ranging from $10 \%$ to $50 \%$ of dry weight [8,9]; but in some genera, such as Botryococcus, the lipid content can reach 60\% to $90 \%$ of dry weight $[10,11]$. Due to their fast growth rate, these microorganisms can be easily cultured in closed bioreactors or open systems and achieve high biomass yields [12], and their cultivation does not compete for resources used in conventional agriculture [13]. Photosynthesis in microalgae is similar to that in higher plants, although characterized by a higher yield compared to terrestrial crops, as it is more efficient in transforming solar energy into chemical energy $[14,15]$. However, microalgal photosynthesis and growth can be affected by several factors, including light supply, temperature, $\mathrm{pH}$, inorganic carbon availability, salinity, and nutrients [15-18]. Particularly, among nutrients, nitrogen $(\mathrm{N})$ is considered one of the most critical for plant-cell growth, since it is a constituent of proteins such as peptides, enzymes, chlorophylls, and energy-transfer molecules [16,19]. In fact, $\mathrm{N}$ 
is the second most abundant element in microalgal cells following carbon (C), ranging from $1 \%$ to $14 \%$ of their dry weight [20]. Due to nitrogen's important roles in cell metabolism, its restriction is often considered a limiting resource for microalgae, and in general for plant growth. Microalgae can utilize different nitrogen forms such as nitrate, nitrite, ammonium, or organic nitrogen (e.g., urea and amino acids). However, the favorable N-form not only differs from species to species, but the diverse N-source also can influence the biochemical composition of the algal cells in different ways [21,22]. In recent years, due to microalgae's ability to use inorganic and organic nitrogen for their growth, their use in treating wastewaters, particularly those rich in ammonium, has been studied [23]. Excess $\mathrm{N}$ discharge into water can lead to eutrophication phenomena in natural aquatic environments, as well as a decline in shellfish habitats and aquatic plant life [24]. The effect of using microalgae in wastewater treatments has been studied by many researchers to make $\mathrm{N}$ removal and the process of eliminating contaminants and pollutants more sustainable [24]. Moreover, when exploiting their metabolic flexibility to grow photo-, hetero- or mixo-trophically, microalgae represent an interesting system for treating a wide range of wastewaters [25].

Water is a very important resource for human development. It is been estimated that a shortage of $40 \%$ of water resources could occur by 2030 [26]. Therefore, the sustainable treatment of wastewater and water reutilization represent an important challenge globally. Ammonium is the one of the most common pollutants in wastewaters. Studies on ammonium-containing wastewater are not limited to its removal, but are also centered on nutrient recycling. The high resistance of some microalgae to high ammonium concentrations makes it possible to use these organisms for bioremediation and wastewater treatment. Furthermore, wastewaters from industrial processes can be characterized not only by high $\mathrm{N}$ concentration, but also by extreme $\mathrm{pH}$ and temperature; in these kinds of effluents, extremophilic microalgae, which are able to grow well in intolerably hostile or even lethal habitats, can be employed. The utilization of microalgae to remove the ammonium content in wastewater, as well as their high-value biomass production, are becoming attractive solutions.

In our review, we explore several issues related to the use of ammonium from microalgae and their sustainable utilization in wastewater treatments (WWT). In particular, the aim of this study is to review recent advancements in microalgal application for ammonium removal from wastewaters. We critically review ammonium recovery in wastewater, especially its biochemical and biological significance in microalgal cultivation. This review seeks to provide new knowledge on the role of microalgae in ammonium removal and the utilization of this nutrient in algal metabolism.

\section{Nitrogen Sources for Microalgae and Ammonium Utilization}

Nitrogen is an essential component in many molecules of all living matter. In the environment, $\mathrm{N}$ actively cycles among water, atmosphere, and soil in different concentrations and forms, such as dinitrogen gas $\left(\mathrm{N}_{2}\right)$, ammonium $\left(\mathrm{NH}_{4}{ }^{+}\right)$, nitrate $\left(\mathrm{NO}_{3}{ }^{-}\right)$, nitrite $\left(\mathrm{NO}_{2}{ }^{-}\right)$, and organic nitrogen (e.g., urea, amino acids, and peptides) [27].

Dinitrogen gas is the most abundant form of $\mathrm{N}$ on Earth ( 78\% in the atmosphere), but it can only be used by a limited number of bacteria and archaea; therefore, it represents an inaccessible source for microalgae and plants in general. The exploitable inorganic $\mathrm{N}$ sources in the environment are $\mathrm{NH}_{4}{ }^{+}, \mathrm{NO}_{3}{ }^{-}$, and $\mathrm{NO}_{2}{ }^{-}$, which show a diverse concentration based on different habitats [28]. In the environment, the most abundant $\mathrm{N}$ source for plant cells is nitrate; however, microalgae are often able to utilize different nitrogen sources based not only on its availability in the environment, but also based on what species they are. In aerated soil, nitrate concentrations can be variable (from 10 to $100 \mathrm{mM}$ ), but the ammonium concentration is generally quite low $\left(<1 \mathrm{mg} \mathrm{Kg}^{-1}\right)$, because it is rapidly converted by bacteria to nitrate [29]. In some acidic and/or anaerobic environments, the ammonium can represent the dominant inorganic form of $\mathrm{N}$ [30]. In ocean waters, the estimated concentration of nitrate is between 7-31 $\mu \mathrm{M}$; of ammonium, $0.001-0.3 \mu \mathrm{M}$; and of nitrite, about 0.006-0.1 $\mu \mathrm{M}$ [28]. 
In plant cell, the assimilation of inorganic nitrogen into amino acids and proteins requires energy and organic skeletons; microalgae such as plants prefer $\mathrm{NH}_{4}{ }^{+}$because the metabolic cost to reduce ammonium to organic matter is lower than the cost for other nitrogen forms reduction [27]. By using ammonium, the microalgae avoid energy consumption due to nitrate/nitrite reduction, but also due to nitrate reductase (NR) and nitrite reductase $(\mathrm{NiR})$ enzymes production $[31,32]$. In fact, in contrast to nitrate and ammonium, subsequent to its transport into the cell, is directly incorporated into amino acids via GS-GOGAT cycle by glutamine synthetase (GS)-glutamate synthase (GOGAT) enzymes (Figure 1), and in some green algae, also under certain conditions, via the NADPglutamate dehydrogenase (GDH) pathway [32,33].

However, some microalgae, such as Botryococcus braunii and Dunaliella tertiolecta, prefer nitrate as an inorganic $\mathrm{N}$ source, showing a reduced growth in the presence of ammonium [22,34].

In addition, ammonium is crucial not only as nutrient, but also as an environmental signal for cellular response [35,36]. In fact, in Chlorella vulgaris, the expression level of GS was up-regulated 6.4-fold under $10 \mathrm{mg} \mathrm{L}^{-1}$ of ammonium compared to that in $4 \mathrm{mg} \mathrm{L}^{-1}$, confirming the key role of GS in ammonium assimilation [36].

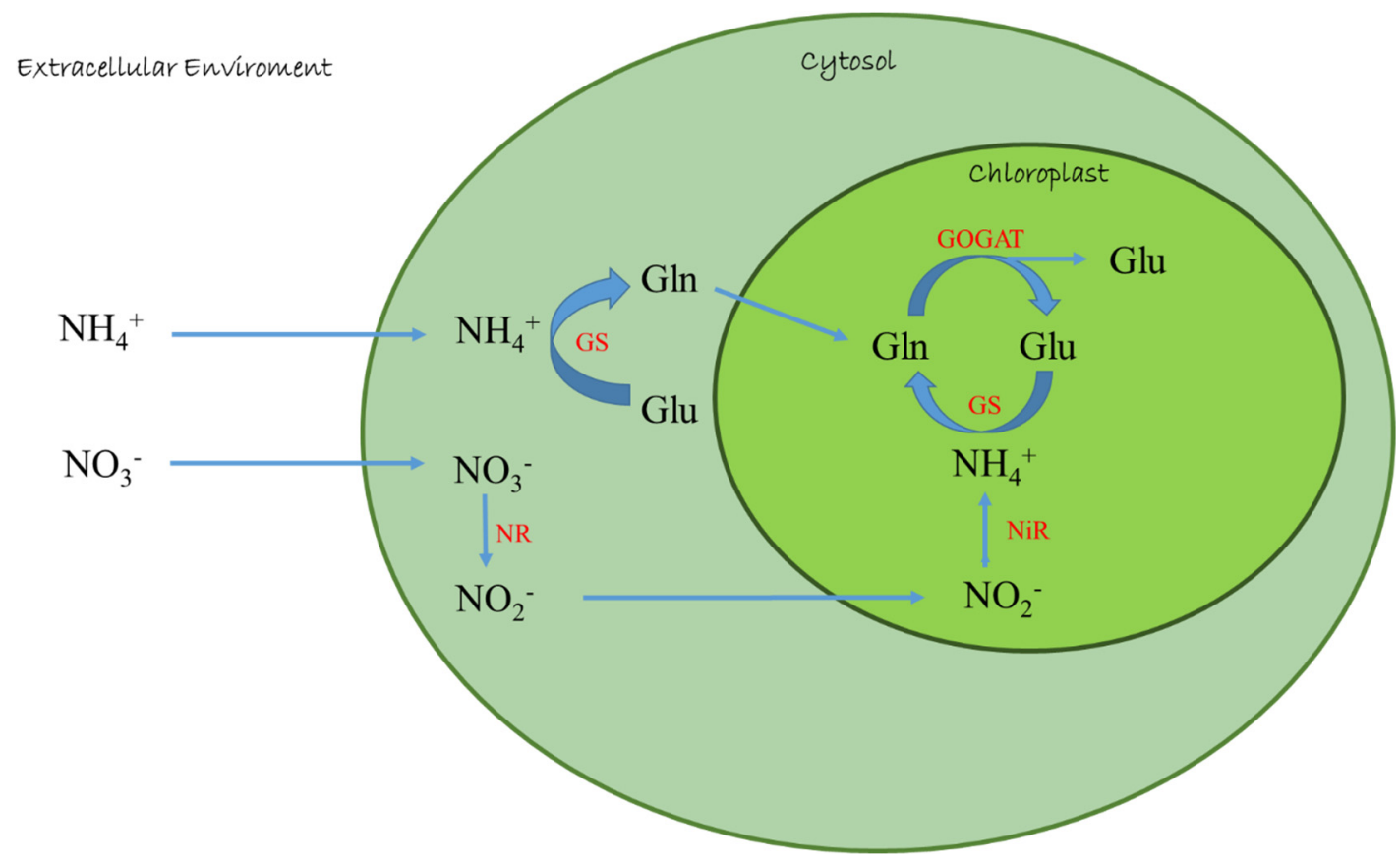

Figure 1. Ammonium and nitrate assimilation in microalgae. NR: Nitrate reductase; NiR: Nitrite reductase; GS: Glutamine synthetase; GOGAT: Glutamate synthase; Glu: Glutamic acid; Gln: Glutamine.

According to Kronzucker et al. [37], there is a short-term inhibition effect of $\mathrm{NH}_{4}{ }^{+}$on nitrate-uptake due to the direct consequences of ammonium on the plasma membrane; this prompt effect is apparent within minutes of $\mathrm{NH}_{4}{ }^{+}$exposure. Inhibition of nitrate uptake is a highly variable process, depending on the species, their physiological status, and on environmental conditions [38]. In fact, for some species of phytoplankton, ammonium concentrations between $100-300 \mathrm{nmol} \mathrm{L}^{-1}$ can be enough to totally suppress nitrate uptake [39], but concentrations up to $1-2 \mu \mathrm{mol} \mathrm{L}^{-1}$ are sometimes necessary for the same effect in other aquatic microorganisms [38]. It was reported that the inhibition of nitrate transport is probably due to the accumulation of a product of ammonium assimilation such as glutamine [40]. In cyanobacteria, ammonium availability results in an immediate inhibition of nitrate uptake; in particular, the bispecific nitrate/nitrite transporter NRT (ABC-type transporter NrtABCD) is repressed, as well as the NR and NiR proteins [41]. On the contrary, in Chlamydomonas acidophila grown in a medium containing $\mathrm{NH}_{4}{ }^{+}$as unique 
source of inorganic $\mathrm{N}$, the $\mathrm{NR}$ activity was low, but not absent; therefore, $\mathrm{NH}_{4}{ }^{+}$replete cells after $\mathrm{N}$-starvation show an $\mathrm{NR}$ activity higher than that of $\mathrm{NO}_{3}{ }^{-}$grown cells [32].

Although the uptake of ammonium is usually fast and preferred to other forms of nitrogen, at important concentrations and prolonged exposure, it may be toxic for algal cells and cause growth inhibition [26,42]. In the follow section, the toxic effect and the tolerance to high ammonium concentration will be discussed.

\section{The Equilibrium Ammonium/Ammonia and Effect on Microalgae}

In the environment, ammonia represents a volatile molecule with very high solubility $\left(\sim 35 \% w / w\right.$ at $\left.25^{\circ} \mathrm{C}\right)$, and for this reason, it is easily found as a liquid solution. In water, the sum of $\mathrm{NH}_{3}$ and $\mathrm{NH}_{4}{ }^{+}$represents the total ammonia nitrogen (TAN) that constitutes a buffer system ammonia/ammonium, as explained by the following formula:

$$
\mathrm{NH}_{4}^{+}+\mathrm{OH}^{-} \leftrightarrow \mathrm{NH}_{3}+\mathrm{H}_{2} \mathrm{O}
$$

This equilibrium between ammonium $\left(\mathrm{NH}_{4}{ }^{+}\right.$; ionized form) and ammonia $\left(\mathrm{NH}_{3}\right.$; unionized form) depends on some parameters; in fact, the two chemical forms are readily interchangeable depending upon the $\mathrm{pH}$, temperature, and salinity of water $[20,43]$.

Being the ion dissociation constant (pKa) of the $\mathrm{NH}_{4}{ }^{+} / \mathrm{NH}_{3}$ buffer system 9.26 at $25^{\circ} \mathrm{C}$, when the $\mathrm{pH}$ of the medium is less than 9.26 , hydrogen ions are incorporated into ammonia to produce ammonium ions that become the dominant species in the medium (Figure 2) [44]. Therefore, as $\mathrm{pH}$ rises, the ammonia concentration increases noticeably.

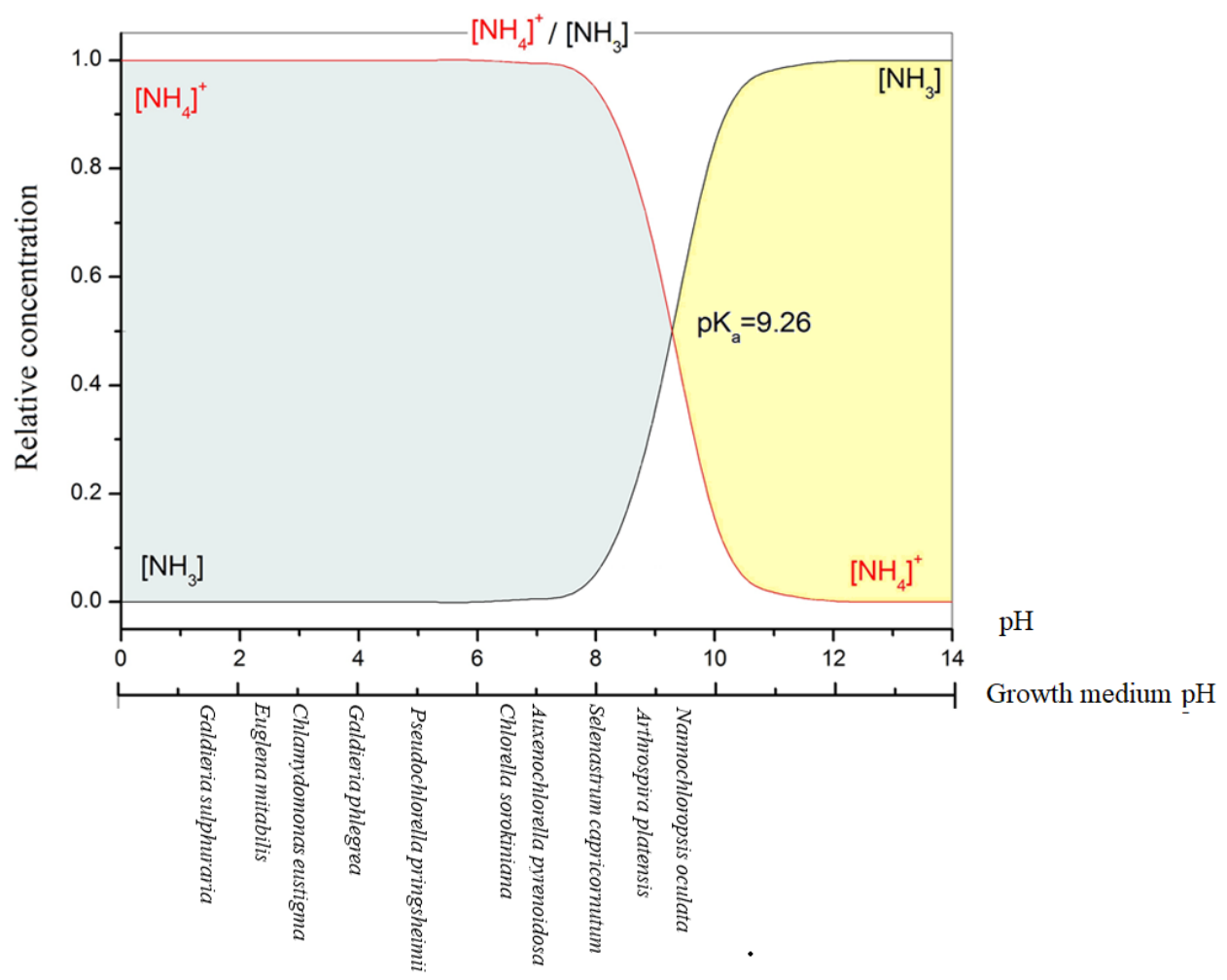

Figure 2. Influence of the $\mathrm{pH}$ on $\mathrm{NH}_{4}{ }^{+} / \mathrm{NH}_{3}$ dissociation equilibrium in water at $25^{\circ} \mathrm{C}$, and the optimum $\mathrm{pH}$ growth of some microalgae.

In natural waters, ammonium is present in much greater concentrations than ammonia due to the prevalence of circum-neutral $\mathrm{pH}$. In fact, it was estimated that in seawater $\left(\mathrm{pH} 8.00,20^{\circ} \mathrm{C}\right), \sim 90 \%$ of TAN is present as ammonium ions [45]. According to Erikson [46], the ratio $\mathrm{NH}_{4}{ }^{+} / \mathrm{NH}_{3}$ increases 10-fold for each rise of $\mathrm{pH}$ unity and 2-fold for each $10{ }^{\circ} \mathrm{C}$ rise of temperature between $0-30{ }^{\circ} \mathrm{C}$. 
The salinity also affects the $\mathrm{NH}_{4}{ }^{+} / \mathrm{NH}_{3}$ equilibrium, but only with minor influence. In fact, a raise in the ionic strength of the medium cause a very small decrease in the ammonia content. An enhancement of salinity from 20 to $34 \%$ leads to a little diminution from 3.41 to $2.98 \%$ of ammonia $[45,47]$.

Usually, cultivation systems of microalgae are enhanced with gaseous inorganic carbon source $\left(\mathrm{CO}_{2}\right)$ to improve the photosynthetic activity and the biomass production. The $\mathrm{pH}$ of the medium and then the $\mathrm{NH}_{4}{ }^{+} / \mathrm{NH}_{3}$ /availability can also depend on the $\mathrm{CO}_{2}$ assimilation rate of the algae [44]. If the $\mathrm{CO}_{2}$ dissolution rate is superior to that of assimilation, the continuous $\mathrm{CO}_{2}$ insufflation leads to an $\mathrm{HCO}_{3}{ }^{-}$and $\mathrm{H}^{+}$accumulation, resulting in the acidification of the culture medium. On the contrary, in the presence of an elevated microalgal assimilation rate, the $\mathrm{CO}_{2}$ assimilation is not enough to satisfy the cells' demand of inorganic carbon; in this case, the carbonate would be assimilated as a C-source by the cell, which makes the $\mathrm{K}^{+} / \mathrm{Na}^{+}$accumulation and the medium alkalization [44].

In an alkaline environment, the ammonia represents the main form; it can diffuse rapidly through membranes different to the ammonium that at low concentrations is taken up by AMT high affinity transporters [28]. Therefore, the ammonia represents the most toxic $\mathrm{N}$ form, having a direct impact on the photosynthetic apparatus of microalgae [42].

For plant cells, the $\mathrm{NH}_{3}$ results are dangerous because it is uncharged and lipid soluble, and thus passes through biological membranes more easily than the ionized form $\mathrm{NH}_{4}{ }^{+}$[48] The toxicity of ammonia in autotrophic microalgae at first occurs through disrupting the thylakoid transmembrane proton gradient $[42,49,50]$. Ammonia, diffusing through cell membranes, affects not only the $\Delta \mathrm{pH}$ component of the thylakoid proton gradient, but also brings oxidative stress. When the $\mathrm{NH}_{3}$ increases, it crosses membranes, leading to enhanced flux through the chloroplast membrane into the thylakoid lumen [49]. Once in the thylakoid lumen, $\mathrm{NH}_{3}$ in the acidic environment is converted to $\mathrm{NH}_{4}{ }^{+}$, thereby decreasing the transmembrane proton gradient needed to power ATP to ADP conversion [49]. Moreover, according to Markou et al. [50], $\mathrm{NH}_{4}{ }^{+}$could affect the Oxygen Evolving Complex (OEC) by shifting a water ligand to the outer Mn cluster of the OEC.

Wang et al. [44] proposed a model of ammonium nitrogen competition between $\mathrm{N}$ assimilation and PSII damage. According to this model, when the adsorbed ammonium was transported into the chloroplast, it could be taken as an inorganic N-source and assimilated by the GS-GOGAT cycle and/or as a dangerous molecule, which primarily damages the OEC and afterward blocks electron transport from $\mathrm{Q}_{\mathrm{A}}{ }^{-}$(primary quinone) to $\mathrm{Q}_{\mathrm{B}}$ (secondary quinone). Therefore, the negative effects on PSII are dependent on the assimilation rate, which is further up to the GS-GOGAT cycle activity [44]. Ammonia compromises the enzymatic activity of some proteins and the lipid peroxidation in membranes, and induces a general cell-level disorder [51].

In ammonium tolerance, the GS/GOGAT activity plays an important role. In Chlorella strains with high performance of the GS/GOGAT cycle, the $\mathrm{NH}_{4}{ }^{+}$is rapidly converted into N-organic molecules, avoiding the ammonium accumulation and toxic effect for the cells [44].

As stated before, the microalgae tolerance to $\mathrm{NH}_{4}{ }^{+} / \mathrm{NH}_{3}$ varies from species to species [44,49]. In fact, while Neochloris oleoabundans and Dunaliella tertiolecta showed an inhibiting growth effect toward ammonia already at 2.3 and $3.3 \mathrm{mg} \mathrm{L}^{-1}$, respectively, Chlorella sorokiniana and Nannochloropsis oculata were largely unaffected by ammonia concentrations (0.2-16.7 $\mathrm{mg} \mathrm{L}^{-1}$ ) [49]. According to Zheng et al. [52], the threshold of $\mathrm{NH}_{4}^{+}$ toxicity in Chlorella vulgaris is around $110 \mathrm{mg} \mathrm{L}^{-1}$, and Collos and Harrison [45] found comparable results. At $\mathrm{NH}_{4}{ }^{+} 110 \mathrm{mg} \mathrm{L}^{-1}$ Chlorella cells maintain high $\mathrm{F}_{\mathrm{v}} / \mathrm{F}_{\mathrm{m}}$ values and a good photosynthetic efficiency [52]. A higher concentration of ammonium $\left(220 \mathrm{mg} \mathrm{L}^{-1}\right)$ corresponds in C. vulgaris to a low cell viability of $61 \%$ [52].

Katayama et al. [13] demonstrated the ammonium tolerance might be acquired as a result of the acclimatization; in fact, two strains of Bacillariophyceae (Thalassiosira weissflogii TRG10-p and TRG10-p105) acclimated up to $180 \mathrm{mg} \mathrm{L}^{-1} \mathrm{NH}_{4}{ }^{+}$, which significantly surpassed the tolerance levels of $65 \mathrm{mg} \mathrm{L}^{-1}$ previously reported by Collos and Harrison [45]. 
According to Chuka-Ogwude [53], under high levels of ammonia, $\mathrm{F}_{\mathrm{v}} / \mathrm{F}_{\mathrm{m}}$ values decreased with the rising $\mathrm{NH}_{3}-\mathrm{N}$ concentration due to the disruption of the photosynthetic apparatus. In acclimated microalgae, cells restore their homeostasis avoiding the toxic effects of the stressor on photosystems.

The establishment of the inhibition of photosynthetic activities occurring in microalgae is of particular importance in algae-based wastewater treatment processes. The resistance or acclimation of some microalgae to high concentrations of ammonium makes it possible to use these organisms for bioremediation and for treatment of wastewater usually rich in ammonium/ammonia content.

\section{Wastewater and Ammonium Content}

Water is the most precious resource of our planet, and according to Adam et al. [26], it could face a global shortage of $40 \%$ by 2030 ; for these reasons, the WWT represents a universal issue for a sustainable solution for water reutilization. Following the world's growth, the spread of wastewater production has become an important environmental problem.

Wastewaters must be treated for environmental protection before being discharged into rivers, lakes, or seas [54]. The variability of the wastewaters (e.g., scales, contaminants, $\mathrm{pH}$, temperature) imposes different managements [25], but in general, wastewater may be dealt with by 1 . primary treatment: It removes sedimentable solid fractions; 2 . secondary treatment: It provides physical/chemical/biological processes, leading to the consumption of organic matter and oxidation of the major nutrients; 3 . tertiary treatment: It allows disinfection and removes nitrogen, phosphorous, and traces of organic molecules [23].

Ammonia nitrogen represents the most common N-containing pollutants usually found in the tertiary stage of conventional wastewater treatment. The removal of macronutrients as nitrogen represents one of the principal criteria for tertiary treatment [23]. A complete and efficient tertiary process, aimed at removing TAN, but also phosphate in wastewater, is usually more expansive than primary treatment [55]. The TAN concentrations vary according to the nature of the wastewater, as shown in the Table 1. In industrial-based wastewater, the ammonium concentrations may be in the range of $5-1000 \mathrm{mg} \mathrm{L}^{-1}$ [26]. Typically, activities such as food processing, rubber processing, textile and leather manufacturing, fertilizer plant, agricultural and zootechnical industries, etc., release high levels of ammonium concentration [56]. Among the high-strength ammonium wastewaters, there is the manure-free piggery wastewater, with a concentration of $\mathrm{NH}_{4}^{+}$of $\sim 220-2945 \mathrm{mg} \mathrm{L}^{-1}$, and wastewaters from coal gasification with $130-280 \mathrm{mg} \mathrm{L}^{-1}[52,57,58]$. Concentrations of $\mathrm{NH}_{4}{ }^{+} / \mathrm{NH}_{3}{ }^{-}$up to $100 \mathrm{mg} \mathrm{L}^{-1}$ are generally derived from anaerobic digestion, when ammonium is produced by degradation of the N-matter in the feedstock, primarily in the form of proteins $[59,60]$. On the other hand, ammonium concentration in the municipal wastewater ranges between 10-200 $\mathrm{mg} \mathrm{L}^{-1}$ [26].

Table 1. $\mathrm{NH}_{3}-\mathrm{NH}_{4}{ }^{+}$concentration $\left(\mathrm{mg} \mathrm{L}^{-1}\right)$ in different wastewater sources.

\begin{tabular}{ccc}
\hline Wastewater Type & $\mathbf{N H}_{\mathbf{3}}-\mathbf{N H}_{\mathbf{4}}{ }^{+}$Concentration $\left.\mathbf{( m g ~ L} \mathbf{~ L}^{-\mathbf{1}}\right)$ & Ref. \\
\hline Municipal wastewater & $27-100$ & {$[61-63]$} \\
Domestic wastewater & $39-60$ & {$[64,65]$} \\
Fish processing wastewater & $8-42$ & {$[66]$} \\
Piggery wastewater & $220-2945$ & {$[16,52,67,68]$} \\
Wool textile mill & 54 & {$[69]$} \\
Coal gasification & $130-280$ & {$[57,58]$} \\
Paper mill & 11 & {$[70]$} \\
Soybean processing & 90 & {$[71]$} \\
Olive mill & 530 & {$[70]$} \\
Winery & 110 & {$[72]$} \\
Coke production & 60 & {$[73]$} \\
Dairy effluent & 49 & {$[74,75]$} \\
\hline
\end{tabular}


Ammonium pollution affects the water quality of water bodies causing numerous environmental problems such as oxygen depletion, $\mathrm{pH}$ shift, cyanotoxin production, and eutrophication of downstream waters: When $\mathrm{N}$ level is higher than $1.9 \mathrm{mg} \mathrm{L}^{-1}$, the water body is considered eutrophic [76,77]. In the last past decades, elevated N-nutrient contents in the water layer have seriously compromised the biodiversity of freshwater ecosystems worldwide [78]. In recent years, many sustainable technologies and methods are studied to remove the TAN from water stream, leading its content under the recommended threshold level from the World Health Organization (WHO) [56].

The TAN abatement in wastewater treatment is usually divided into different approaches: Physical (e.g., membrane separation), chemical (e.g., coagulation, solvent extraction, ion exchange,), and/or biological [23,56,79]. The high effective cost and energy consumption of technologies for one-step tertiary treatment of WWT represent a problem for industries and municipalities [80]. A valid alternative to conventional treatments may be provided by microalgae, coupling the nutrient removal from wastewater with the production of valuable biomass.

\section{Microalgae in Wastewater Treatment for Ammonium Removal}

In the last decade, microalgae have become important organisms for biological purification of wastewater due their ability to utilize and/or accumulate nutrients, heavy metals, and organic and inorganic substances in their cells/bodies. The use of microalgae for WWT requires a minimum of mechanical equipment and reasonably little energy consumption for their operations $[81,82]$. In wastewaters, $\mathrm{N}$ concentration must be reduced to acceptable limits (generally $<10-15 \mathrm{mg} \mathrm{L}^{-1}$ depending on discharge point, population, and region regulation as described by regulation 91/271/CEE) before being released into the water body [83]. Many studies demonstrated that microalgae have a great potential for $\mathrm{N}$ removal and reported successful cultivations [13,23-25,52,80]. Green microalgae (Chlorophyceae) represent the more exploited algae in WWT (Table 2).

It was calculated that for 1-ton microalgal production, about $40-100 \mathrm{Kg}$ of inorganic Ncompound and 11-13 ML/Ha/year of water are required. It was also estimated that about $2500 \mathrm{~m}^{3}$ of wastewater to obtain 1-ton of microalgal biomass could be treated [80]. Therefore, at the same time, the utilization of wastewater for algal cultivation could allow the removal nutrients from effluents and reduce the use of precious freshwater. According to Yang and colleagues [84], using wastewater for microalgal cultivation would reduce $\sim 90 \%$ of the water demand and eliminate the requirement for nutrients. Wastewater could afford most essential resources for large-scale of microalgal cultivation by providing inorganic nutrients and organic matter for mixo- or heterotrophic cultures. In autotrophic microalgae cultivation, algae can give a further possibility of integrating the nutrient removal with carbon capture: $\mathrm{CO}_{2}$ can be incorporated into biomolecules as proteins, carbohydrates, and lipids by photosynthetic reactions [55]. Therefore, phototrophic cultivations could represent a single-step solution to reduce the $\mathrm{CO}_{2}$ emission as well as the eutrophication by nitrogen $[76,85]$.

In a culture medium, an ammonium concentration higher than $100 \mathrm{mg} \mathrm{L}^{-1}$ inhibits the photosynthesis in some microalgal species $[42,45,66]$. Recently, several studies have been conducted to alleviate TAN toxicity and to optimize the cell ammonium assimilation in microalgal cultures and wastewater treatment [20,42,45]. It was reported that a high concentration of TAN could be mitigated by increasing the initial culture cells concentration, modulating light intensity, and/or monitoring the $\mathrm{pH}$ of their medium $[20,42,50,86]$. In addition, microalgal growth and biomass yield are less affected by high ammonium concentration using a mixotrophic cultivation; in fact, mixotrophic cells can provide more energy for fast ammonium assimilation, reducing ammonium inhibition and increasing the microalgal biomass [42].

According to recent studies (Table 2), microalgal systems can efficiently treat many kinds of ammonium-containing-wastewaters: Domestic and urban wastewaters, livestock 
wastes, agro-industrial wastewater, piggery effluent, effluent from food processing factories, and so on.

To optimize the nutrient removal, microalgae can be employed in WWT as monoculture, consortia, or combined systems. Monoculture or consortia systems refer to systems using only a single or a consortium of microalgae for nutrient removal without the support of other organisms [82]. Otherwise, combined systems use both microalgae and bacteria for an efficient removal of nutrients (such as ammonium) and organic matter [82]. An interesting symbiosis for ammonium abatement is represented by nitrifying bacteria (e.g., Nitromonas and Nitrobacter) and microalgae. Bacteria oxidizes ammonium into nitrite and then to nitrate, and from the other side, microalgae by photosynthesis supply $\mathrm{O}_{2}$ for oxidation and utilize $\mathrm{CO}_{2}$, deriving from bacterial respiration, for the Calvin-Benson cycle $[82,87]$.

Definitively, microalgae exploited in WWT represent an extensive area of research and development with enormous potential. Although many studies were conducted regarding the possibility of using microalgae as nutrient removers from wastewater, today only a few studies regard algal cultivation under continuous wastewater administration [88]. Wastewater treatment is a global issue on which much research is still ongoing. In fact, freshwater has become a limited resource in many areas of the world. Continuous cultivation of microalgae with wastewater could not only provide a continuous supply of microalgae biomass, but it would also represent a great sustainable process for recycling wastewater. 
Table 2. An overview of recent WWT research on microalgae.

\begin{tabular}{|c|c|c|c|c|c|c|c|c|}
\hline Class & Species & Strain & Wastewater Type & $\mathrm{pH}$ & $\begin{array}{l}\mathrm{NH}_{4}^{+}-\mathrm{N} \\
\left(\mathrm{mg} \mathrm{L}^{-1}\right)\end{array}$ & $\underset{(\%)}{\mathrm{NH}_{4}{ }^{+}-\mathrm{N} \text { Removal }}$ & $\begin{array}{l}\text { Removal Time } \\
\text { (Days) }\end{array}$ & Ref. \\
\hline \multirow[t]{17}{*}{ Chlorophyceae } & Chlorella sorokiniana & UTEX 2805 & Synthetic wastewater & - & 10 & 100 & 5 & [89] \\
\hline & Chlorella sorokiniana & UTEX 1230 & Digested from cattle manure & - & 893 & 75 & 25 & [90] \\
\hline & Chlorella sorokiniana & UTEX 2714 & Digested from cattle manure & - & 893 & 59 & 25 & [90] \\
\hline & Chlorella sorokiniana & CS-01 & Digested from cattle manure & - & 893 & 75 & 25 & [90] \\
\hline & Chlorella sorokiniana & - & Potato processing wastewater & 5.8 & 12 & $>95$ & 30 & [91] \\
\hline & Chlorella sorokiniana & - & Secondary pig manure & 7.5 & 12 & 83 & 30 & [91] \\
\hline & Chlorella vulgaris & FACHB-30 & Piggery wastewater & 6.3 & 220 & 50 & 7 & [52] \\
\hline & Chlorella vulgaris & - & Domestic wastewater & $7.3-8.4$ & $2.7-11$ & $80-87$ & 1 & [92] \\
\hline & Chlorella vulgaris & LEM 07 & Domestic wastewater & 7.2 & 13 & - & - & [93] \\
\hline & Chlorella minutissima & - & Domestic wastewater & 7.2 & 13 & - & - & [93] \\
\hline & Chlorella zofingiensis & - & Piggery wastewater & 6.2 & - & $65-80$ & 4 & [93] \\
\hline & $\begin{array}{l}\text { Chlamydomonas } \\
\text { reinhardtii }\end{array}$ & - & Landfill leachate & 7 & 760 & 70 & 40 & {$[80]$} \\
\hline & Coelastrum microporum & IFA9 & Municipal wastewater & 7.3 & - & - & - & [62] \\
\hline & Graesiella emersonii & ATCC 13482 & Synthetic wastewater & - & $4-16$ & $>99$ & 18 & [88] \\
\hline & Neochloris oleoabundans & LEM 17 & Domestic wastewater & 7.2 & 13 & - & - & [93] \\
\hline & Scenedesmus sp & - & Anaerobic digestate & 8 & $50-260$ & $60-100$ & 7 & [95] \\
\hline & Scenedesmus sp & - & Fertilizer Plant Wastewater & 7.3 & 27 & 93 & 10 & [96] \\
\hline \multirow[t]{3}{*}{ Cyanidiophyceae } & Galdieria sulphuraria & CCMEE 5587.1 & Urban wastewater & $1-4$ & $15-25$ & $63-89$ & 6 & [97] \\
\hline & Galdieria sulphuraria & CCMEE 5587.1 & Primary wastewater effluent & 2.5 & 40 & 88 & 7 & [98] \\
\hline & Galdieria sulphuraria & 074G & Food waste hydrolysates & 2 & 500 & - & - & [99] \\
\hline \multirow[t]{7}{*}{ Cyanophyceae } & Nostoc sp. & - & Food-industry wastewater & $7.6-9.8$ & 44 & - & - & [100] \\
\hline & Arthrospira platensis & - & Food-industry wastewater & $8.6-8.9$ & $38-61$ & - & - & [100] \\
\hline & Phormidium tergestinum & - & Slaughterhouse wastewater & 9.2 & - & - & - & [101] \\
\hline & Porphyridium purpureum & - & Food-industry wastewater & $8.6-8.9$ & $43-58$ & - & - & [100] \\
\hline & Synechoccus nidulans & LEM06 & Domestic wastewater & 7.2 & 13 & - & - & [93] \\
\hline & Thermosynechococcus & CL-1 & Anoxic swine wastewater & 7.2 & 359 & $50-100$ & 0.5 & [102] \\
\hline & Thermosynechococcus & CL-1 & Aerobic swine wastewater & 7.5 & 182 & $30-60$ & 0.5 & [102] \\
\hline \multirow[t]{3}{*}{ Trebouxiophyceae } & Botryococcus braunii & LEM 14 & Domestic wastewater & 7.2 & 13 & - & - & [93] \\
\hline & Botryococcus braunii & UTEX LB 572 & Domestic effluent & 6.4 & 8 & $62-63$ & 60 & [103] \\
\hline & Botryococcus braunii & BL C116 & Domestic effluent & 6.4 & 8 & $61-65$ & 60 & [103] \\
\hline
\end{tabular}




\section{Extremophilic Microalgae in WWT}

Extremophile microalgae are organisms that are able to grow well in intolerably hostile or even lethal habitats, and which could represent a good solution for treatment of "extreme wastewaters". They can grow well under extreme $\mathrm{pH}$, temperatures, salinity, light intensities, nutrients available, and heavy metal concentrations. However, $\mathrm{pH}$ and temperature are the major constraints affecting $\mathrm{NH}_{4}{ }^{+} / \mathrm{NH}_{3}$ equilibrium in wastewater, and for this reason, only these two will be discussed below.

In specific cases, wastewaters from industrial processes are characterized by high TAN concentration and extreme $\mathrm{pH}(4.00>\mathrm{pH}>8.00)$ and /or temperature $\left(10^{\circ} \mathrm{C}>\mathrm{C}>40^{\circ} \mathrm{C}\right)$ that are not compatible with the metabolism of most microalgae species [25]. For example, water draining from the sites of mines is frequently rich in sulphate (100 to $>5000 \mathrm{mg} \mathrm{dm}^{-3}$ ), and it is acid with $\mathrm{pH}<4$ [104]. These kinds of wastewaters are highly polluting and toxic to most life forms; if untreated, they may devastate the streams and rivers into which they flow [104]. Acid wastewaters are usually derived from ammunition industries/labs, pharmaceutical industries, mining sites, steel industry, electroplating and phosphorous industries and, in many cases, their drainage is treated so as to be neutralized before being released into the environment $[105,106]$. The low $\mathrm{pH}$ wastewater causes numerous problems in the effluent treatment as well as in the water body in which it is discharged [105]. Furthermore, a highly acidic medium breaks down organic matter and eradicates microbial organisms able to treat the water naturally [105].

In environments with low $\mathrm{pH}$, the number of algae able to survive are limited compared to a neutrophilic environment. Microalgae described to be metabolically active in highly acidic environments include some Chlorophyta, such as Chlamydomonas acidophila and Dunaliella acidophila, Chrysophyta, such as Ochromonas sp., and Euglenophyta, such as Euglena mutabilis [107]. Poliextremophiles Rhodophyta (Cyanidium caldarium, Galdieria sulphuraria, Galdieria phlegrea, and Galdieria maxima), frequently encountered in acidic waters and in geothermal areas of the world [19,107-109], can be employed in the treatment of these "extreme wastewaters".

Red microalgae of the genus Galdieria (Cyanidiaceae) represent a very interesting organism, growing in cryptoendolithic habitats with $\mathrm{pH}$ ranging $0.50-4.00$ [17,107-109]. All Galdieria species are able to grow in the dark (heterotrophically) or in the light (mixotrophically) by using numerous carbon sources as organic substrates, with about 50 different carbon sources such as sugars, sugar alcohols, tricarboxylic-acid-cycle intermediates, and amino acids $[17,108,110]$. Galdieria sp., being acidophilic organisms, colonize habitats with very low $\mathrm{pH}$ in which the more available nitrogen form is present as ammonium; for this reason, these organisms are well adapted to utilize $\mathrm{NH}_{4}{ }^{+}$as a principal source of inorganic nitrogen and to tolerate prolonged exposure to this nutrient. According to HenkanatteGederaet et al. [97], Galdieria sulphuraria is able to grow well in filtered primary-settled urban wastewater $(\mathrm{pH} 2.5)$, considerably reducing organic carbon (46-72\%) and ammoniacal nitrogen $(63-89 \%)$, and it is able to grow on primary effluents, showing a high nutrient removal rate [98].

In WWT, another important parameter for $\mathrm{NH}_{4}{ }^{+} / \mathrm{NH}_{3}$ equilibrium is the temperature. The wastewater temperature can depend on the production process of derivation, but also on the climate of the region in which it is produced. In fact, according to Bugajski et al. [111], a significant correlation between the temperatures of wastewater with the air temperatures exists. Therefore, in the coldest and hottest regions, the wastewater is strongly influenced by seasonal and night/day temperatures.

The increase in the temperature of the wastewater causes a change in the solubility of oxygen, an acceleration of the oxygen adsorption process, the rate of bacteria activity, and of some chemical and biological processes [112,113]. In particular, the free ammonia proportion at $25^{\circ} \mathrm{C}$ relative to the TAN is about two-fold compared with $15^{\circ} \mathrm{C}[112,114]$. There are three types of microalgae concerning the supporting temperature (Figure 3): 1. Mesophiles: Living at temperatures ranging between $15-45^{\circ} \mathrm{C}\left(\mathrm{T}{ }^{\circ} \mathrm{C}\right.$ optimum $\left.\sim 32.5^{\circ} \mathrm{C}\right)$; 2. thermophiles: Growing at temperatures ranging between 40 to $75^{\circ} \mathrm{C} ; 3$. psychrophiles: 
Growing in temperatures ranging between 0 and $20^{\circ} \mathrm{C}$. Thermophiles and psychrophiles represent the extremophile organisms, which are not only able to tolerate prohibitive conditions, but require them for their metabolism [113].

In a wastewater pond in India, where the temperature ranges between $37-43{ }^{\circ} \mathrm{C}$, two green algae, Asterarcys quadricellulare and Chlorella sorokiniana, were isolated [113]. Most of the reported strains of Chlorella grow in an optimum range between $25-32{ }^{\circ} \mathrm{C}$, however, some strains, after acclimation, become thermotolerant and can tolerate temperatures of $40{ }^{\circ} \mathrm{C}$ or higher $[89,113]$.

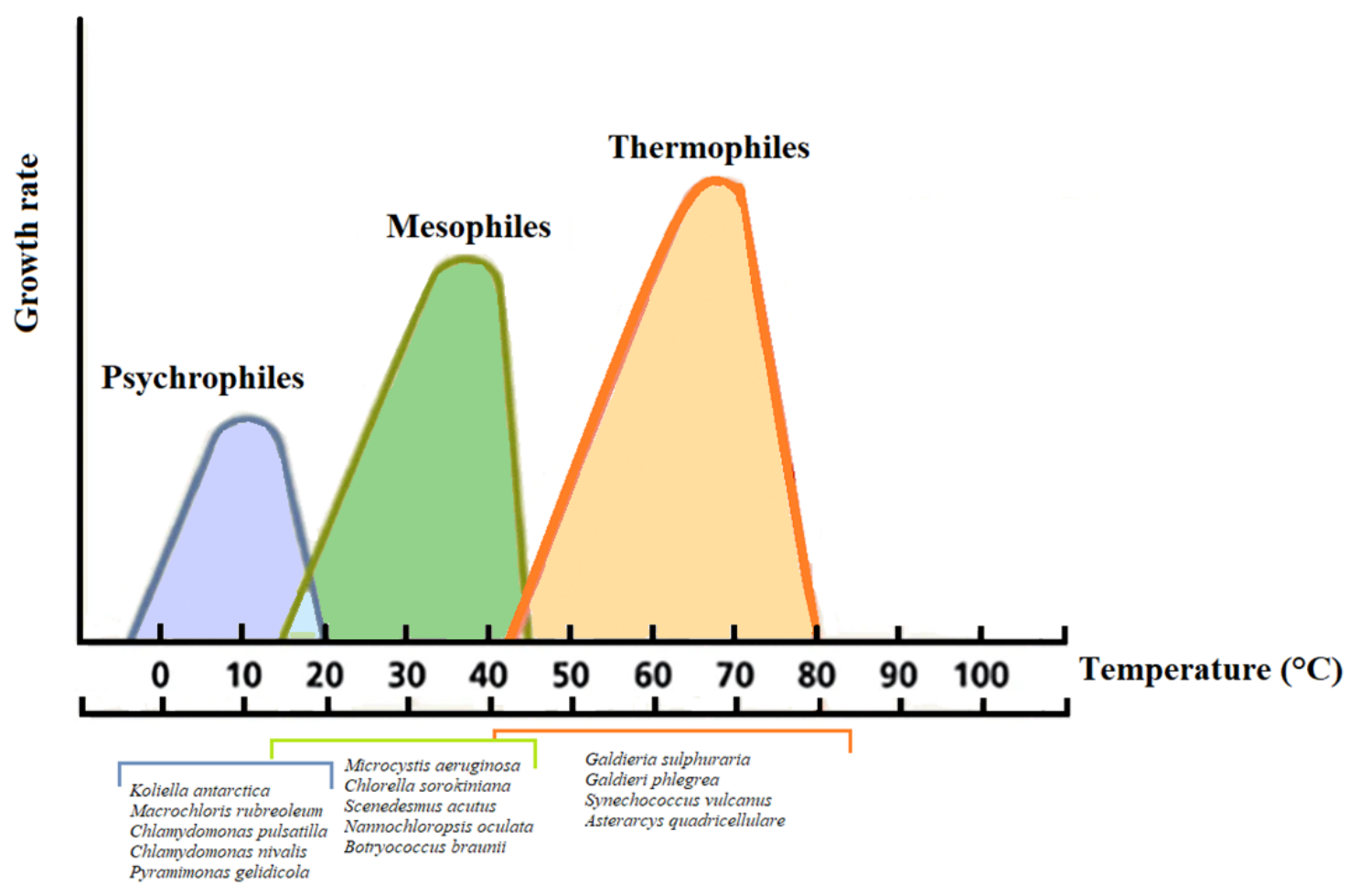

Figure 3. Relation of temperature and growth rates for representative psychrophilic, mesophilic, and thermophilic microalgae.

Another challenge is the treatment of low temperature wastewaters. In fact, a large variety of wastewaters, including domestic sewage and industrial wastewater, such as those from bottling, malting, brewery, and soft drink manufacturing plants, are characterized by low temperatures, and their heating is required, thus raising the costs of this waste treatment $[115,116]$. Systems based on psychrophilic microalgae able to operate at low temperatures $\left(10-20^{\circ} \mathrm{C}\right)$ offer the possibility to reduce the energy costs.

Koliella antarctica is a genus of psychrophilic unicellular green alga belonging to the class of Trebouxiophyceae [117]. Koliella cells can be grown in a laboratory at a temperature as low as $2{ }^{\circ} \mathrm{C}$, but can adapt to different physical environmental parameters such as temperature (from -2 to $20^{\circ} \mathrm{C}$ ) and light (from 8 to $60 \mu \mathrm{mol}$ photons $\mathrm{m}^{-2} \mathrm{~s}^{-1}$ ); they represent an interesting potential biological system for treatment of low temperature wastewater, such as water from fresh fruit processing industries [25,117-119].

The extremophiles have shown to be promising for WWT, and for bioremediation. Many of industrial wastes have harsh conditions, which make extremophiles and polyextremophiles a good choice for their treatment before releasing them into the environment [120].

\section{High-Value Molecules from Microalgae Exploited in WWT}

The integration of microalgae with WWT offers promising opportunities to reduce the treatment costs, to recycle the nutrients, and to obtain sustainable useful bioproducts (proteins, pigments, lipids, carbohydrates, biofuel, etc.) [25]. The employment of appropri- 
ate microalgal species in WWT allows for the hyperaccumulation of valuable bioproducts without compromising the cells' growth and their biomass increase.

The microalgae Scenedesmus strain SDEC8, grown in anaerobically digested effluent kitchen waste, can accumulate more biomass than Scenedesmus SDEC13 grown in the same culture medium [121]. This result indicates the importance of a proper choice of the algal species and of the strain for WWT aiming to biomass or biomolecules production. In fact, the ability to grow in the various wastewaters varies from species to species, and it is surely strain dependent.

Prospectively, to reduce the economic costs of biofuel from algae, wastewater has been proposed as an alternative nutrient source for microalgae cultivation [25,103]. According to Rinna et al. [103], Botryococcus braunii (strain LB572), grown in domestic wastewater effluent, shows not only an efficient nitrogen consumption, but also an effective intracellular lipid production and accumulation, in particular regarding saturated fatty acids. Growing algae in a low-cost medium is necessary to diminish the cost of microalgal cultivation and to make the biofuel production a more economic and environment-friendly process [122]. In Chlorella vulgaris, the biomass and lipid contents are appreciably higher for cells cultivated in urban wastewater than in the basal medium since the lipid productivity that results is about 1.5 times higher in cells cultivated in wastewater [122]. In contrast to biomass production and productivity, the highest lipid accumulation was reached in microalgae such as Chlorella ellipsoidea and Scenedesmus sp., cultivated in domestic secondary effluent, characterized by low $\mathrm{N}$ content $[8,123,124]$. In fact, in some species of microalgae, lipid content can reach up to $80 \%$, usually under N-deficiency conditions [10,11]. For this reason, in wastewaters, lipid productivity can be enhanced by two-stage cultivation, where lipid content increases during the second stage characterized by N starvation [125].

The algal biomass also constitutes a valuable source of pigments, mainly chlorophylls and carotenoids, which have been correlated with several health benefits [125]. From Phormidium autumnale, grown under heterotrophic cultivation in slaughterhouse waste, carotenoids at industrial scale to 108-ton year are produced [125,126]. In Thermosynechococcus sp., grown in aerobic treated swine wastewater, satisfactory phycobiliprotein and carotenoid contents were obtained [102].

The cyanobacterium Arthrospira platensis and the Rhodophytes Porphyridium sp. and Galdieria sp. are the principal producers of phycobiliproteins $[19,100,108]$. Phycobiliproteins, in particular phycocyanin, have high commercial value as antioxidant and antiinflammatory molecules and represent safer ingredients for food, nutraceutical, and pharmaceutical purposes $[3,108,109]$. The production of these pigments from microalgae cultivated in wastewater has not been significantly explored. According to Arashiro and colleagues [100], the cultivations of Nostoc sp., Arthrospira platensis, and Porphyridium purpureum in food-industry wastewater showed efficient treatment of the wastewater, reaching high removal of nutrients and interesting phycobiliproteins accumulation in algal biomass.

Several microalgal species, such as Chlorella ssp., Arthrospira platensis, Scenedesmus sp., Botryococcus braunii, and many others, show high nutrient removal capacity in wastewater and return valuable molecules $[100,103,123,124]$. The application of these strategies for microalgae utilization in WWT needs further study, but opens great possibilities in the ammonium mitigation from effluents and in sustainable biomolecules production.

\section{Conclusions}

An excess of ammonium in water bodies can lead to an eutrophication phenomenon in natural environments. For this, WWT represent an important global issue. The modern WWT technologies in use are considered efficient in processing, but they necessitate a lot of energy and do not contemplate the recycling of useful nutrients such as ammonium. Microalgae are photo-, mixo-, and heterotrophic organisms that can be used in WWT for removal of the inorganic nitrogen and of other pollutants. To improve the conventional WWT, the utilization of microalgae for nutrient removal could represent a sustainable 
solution. In fact, being algae producers of biologically active compounds, their biomass obtained by WWT can be exploited as biomolecule sources.

Further research needs to focus on continuous microalgae cultivation in wastewater that could not only provide a continuous supply of biomass, but would also represent a great sustainable process for recycling wastewater.

Author Contributions: The authors contributed equally to this work. All authors have read and agreed to the published version of the manuscript.

Funding: This research received no external funding.

Institutional Review Board Statement: Not applicable.

Informed Consent Statement: Not applicable.

Conflicts of Interest: The authors declare that the research was conducted in the absence of any commercial or financial relationships that could be construed as a potential conflict of interest.

\section{References}

1. Mata, T.M.; Martins, A.A.; Caetano, N.S. Microalgae for biodiesel production and other applications: A review. Renew. Sustain. Energy Rev. 2010, 14, 217-232. [CrossRef]

2. De Morais, M.G.; de Fontoura Prates, D.; Moreira, J.B.; Duarte, J.H.; Costa, J.A.V. Phycocyanin from microalgae: Properties, extraction and purification, with some recent applications. Ind. Biotechnol. 2018, 14, 30-37. [CrossRef]

3. Bottone, C.; Camerlingo, R.; Miceli, R.; Salbitani, G.; Sessa, G.; Pirozzi, G.; Carfagna, S. Antioxidant and anti-proliferative properties of extracts from heterotrophic cultures of Galdieria sulphuraria. Nat. Prod. Res. 2019, 15, 1-5. [CrossRef] [PubMed]

4. Vidanarachchi, J.K.; Kurukulasuriya, M.S.; Malshani Samaraweera, A.; Silva, K.F.S.T. Applications of Marine Nutraceuticals in Dairy Products. Adv. Food Nutr. Res. 2012, 65, 457-478. [PubMed]

5. De Jesus Raposo, M.F.; De Morais, R.M.S.C.; De Morais, A.M.M.B. Bioactivity and applications of sulphated polysaccharides from marine microalgae. Mar. Drugs 2013, 11, 233-252. [CrossRef] [PubMed]

6. Camacho, F.; Macedo, A.; Malcata, F. Potential Industrial Applications and Commercialization of Microalgae in the Functional Food and Feed Industries: A Short Review. Mar. Drugs 2019, 17, 312. [CrossRef]

7. Napolitano, G.; Fasciolo, G.; Salbitani, G.; Venditti, P. Chlorella sorokiniana Dietary Supplementation Increases Antioxidant Capacities and Reduces ROS Release in Mitochondria of Hyperthyroid Rat Liver. Antioxidants 2020, 9, 883. [CrossRef]

8. Wu, H.Y.; Hu, H.Y.; Yu, Y.; Zhang, T.Y.; Zhu, S.F.; Zhuang, L.L.; Zhang, X.; Lu, Y. Microalgal species for suitable biomass/lipid production using wastewater as resources: A review. Renew. Sustain. Energy Rev. 2014, 33, 675-688. [CrossRef]

9. Sun, X.M.; Ren, L.J.; Zhao, Q.Y.; Ji, X.J.; Huang, H. Microalgae for the production of lipid and carotenoids: A review with focus on stress regulation and adaptation. Biotechnol. Biofuels 2018, 11, 272. [CrossRef]

10. Metting, F.B. Biodiversity and application of microalgae. J. Microbiol. Bioech. 1996, 17, 477-489. [CrossRef]

11. Salbitani, G.; Barone, C.M.A.; Carfagna, S. Effect of bicarbonate on growth of the oleaginous microalga Botryococcus braunii. Int. J. Plant. Biol. 2019, 10, 8273. [CrossRef]

12. Serive, B.; Kaas, R.; Bérard, J.B.; Pasquet, V.; Picot, L.; Cadoret, J.P. Selection and optimisation of a method for efficient metabolites extraction from microalgae. Bioresour. Technol. 2012, 124, 311-320. [CrossRef] [PubMed]

13. Katayama, T.; Nagao, N.; Kasan, N.A.; Khatoon, H.; Rahman, N.A.; Takahashi, K.; Furuya, K.; Yamada, Y.; Wahid, M.E.A.; Jusoh, M. Bioprospecting of indigenous marine microalgae with ammonium tolerance from aquaculture ponds for microalgae cultivation with ammonium-rich wastewaters. J. Biotechnol. 2020, 323, 113-120. [CrossRef] [PubMed]

14. Giuliano, G.; Demurtas, O.; Ferrante, P. Le microalghe come bio-fabbriche per composti ad elevato valore aggiunto. ENEA Mag. EAI Speciale Biotecnologie per lo Sviluppo Sostenibile 2013, I, 61-66.

15. Salbitani, G.; Bolinesi, F.; Affuso, M.; Carraturo, F.; Mangoni, O.; Carfagna, S. Rapid and positive effect of bicarbonate addition on growth and photosynthetic efficiency of the green microalgae Chlorella sorokiniana (Chlorophyta, Trebouxiophyceae). Appl. Sci. 2020, 10, 4515. [CrossRef]

16. Kim, G.; Mujtaba, G.; Lee, K. Effects of nitrogen sources on cell growth and biochemical composition of marine chlorophyte Tetraselmis sp. for lipid production. Algae 2016, 31, 257-266. [CrossRef]

17. Carfagna, S.; Bottone, C.; Cataletto, P.R.; Petriccione, M.; Pinto, G.; Salbitani, G.; Vona, V.; Pollio, A.; Ciniglia, C. Impact of sulfur starvation in autotrophic and heterotrophic cultures of the Extremophilic Microalga Galdieria phlegrea (Cyanidiophyceae). Plant Cell Physiol. 2016, 57, 1890-1898. [CrossRef]

18. Salbitani, G.; Del Prete, S.; Bolinesi, F.; Mangoni, O.; De Luca, V.; Carginale, V.; Donald, W.A.; Supuran, C.T.; Carfagna, S.; Capasso, C. Use of an immobilized thermostable $\alpha$-CA (SspCA) for enhancing the metabolic efficiency of the freshwater green microalga Chlorella sorokiniana. J. Enzym. Inhib. Med. Chem. 2020, 35, 913-920. [CrossRef]

19. Salbitani, G.; Carfagna, S. Different behavior between autotrophic and heterotrophic Galdieria sulphuraria (Rhodophyta) cells to nitrogen starvation and restoration. Impact on pigment and free amino acid contents. Int. J. Plant. Biol. 2020, 11, 8567. [CrossRef] 
20. Markou, G.; Vandamme, D.; Muylaert, K. Microalgal and cyanobacterial cultivation: The supply of nutrients. Water Res. 2014, 65, 186-202. [CrossRef]

21. Arumugam, M.; Agarwal, A.; Arya, M.C.; Ahmed, Z. Influence of nitrogen sources on biomass productivity of microalgae Scenedesmus bijugatus. Bioresour. Technol. 2013, 131, 246-249. [CrossRef] [PubMed]

22. Ruangsomboon, S. Effects of different media and nitrogen sources and levels on growth and lipid of green microalga Botryococcus braunii KMITL and its biodiesel properties based on fatty acid composition. Bioresour. Technol. 2015, 191, 377-384. [CrossRef] [PubMed]

23. Molazadeh, M.; Ahmadzadeh, H.; Pourianfar, H.R.; Lyon, S.; Rampelotto, P.H. The Use of Microalgae for Coupling Wastewater Treatment with $\mathrm{CO}_{2}$ Biofixation. Front. Bioeng. Biotechnol. 2019, 7, 42. [CrossRef] [PubMed]

24. Jia, H.; Yuan, Q. Removal of nitrogen from wastewater using microalgae and microalgae-bacteria consortia. Cogent. Environ. Sci. 2016, 2, 1275089. [CrossRef]

25. Wollmann, F.; Dietze, S.; Ackermann, J.U.; Bley, T.; Walther, T.; Steingroewer, J.; Krujatz, F. Microalgae wastewater treatment: Biological and technological approaches. Eng. Life Sci. 2019, 19, 860-871. [CrossRef] [PubMed]

26. Adam, M.R.; Othman, M.H.D.; Samah, R.A.; Puteh, M.H.; Ismail, A.F.; Mustafa Rahman, M.A.; Jaafar, J. Current trends and future prospects of ammonia removal in wastewater: A comprehensive review on adsorptive membrane development. Sep. Purif. Technol. 2019, 213, 114-132. [CrossRef]

27. Mandal, S.; Shurin, J.B.; Efroymson, R.A.; Mathews, T.J. Functional divergence in nitrogen uptake rates explains diversityproductivity relationship in microalgal communities. Ecosphere 2018, 9, e02228. [CrossRef]

28. Sanz-Luque, E.; Chamizo-Ampudia, A.; Llamas, A.; Galvan, A.; Fernandez, E. Understanding nitrate assimilation and its regulation in microalgae. Front. Plant. Sci. 2015, 26, 899. [CrossRef]

29. Ouyang, Y.; Norton, J.M.; Stark, J.M.; Reeve, J.R.; Habteselassie, M.Y. Ammonia-oxidizing bacteria are more responsive than archaea to nitrogen source in an agricultural soil. Soil Biol. Biochem. 2016, 96, 4-15. [CrossRef]

30. Hachiya, T.; Sakakibara, H. Interactions between nitrate and ammonium in their uptake, allocation, assimilation, and signaling in plants. J. Exp. Bot. 2017, 68, 2501-2512. [CrossRef]

31. Pritchard, D.W.; Hurd, C.L.; Beardall, J.; Hepburn, C.D. Restricted use of nitrate and a strong preference for ammonium reflects the nitrogen ecophysiology of a light-limited red alga. J. Phycol. 2015, 51, 277-287. [CrossRef] [PubMed]

32. Lachman, S.; Mettler-Altmann, T.; Wacker, A. Nitrate or ammonium: Influences of nitrogen source on the physiology of a green alga. Ecol. Evol. 2018, 9, 1070-1082. [CrossRef] [PubMed]

33. Hellebust, J.A.; Ahmad, I. Regulation of Nitrogen Assimilation in Green Microalgae. Biol. Oceanogr. 1989, 6, $241-255$.

34. Chen, M.; Tang, H.; Ma, H.; Holland, T.C.; Ng, K.Y.; Salley, S.O. Effect of nutrients on growth and lipid accumulation in the green algae Dunaliella tertiolecta. Bioresour. Technol. 2011, 102, 1649-1655. [CrossRef] [PubMed]

35. Stitt, M.; Müller, C.; Matt, P.; Gibon, Y.; Carillo, P.; Morcuende, R.; Scheible, W.R.; Krapp, A. Steps towards an integrated view of nitrogen metabolism. J. Exp. Bot. 2002, 53, 959-970. [CrossRef]

36. Liu, Q.; Chen, X.; Wu, K.; Fu, X. Nitrogen signaling and use efficiency in plants: What's new? Curr. Opin. Plant. Biol. 2015, 27, 192-198. [CrossRef]

37. Kronzucker, H.J.; Glass, A.D.; Yaeesh Siddiqi, M. Inhibition of nitrate uptake by ammonium in barley. Analysis Of component fluxes. Plant. Physiol. 1999, 120, 283-292. [CrossRef]

38. L'Helguen, S.; Maguer, J.F.; Caradec, J. Inhibition kinetics of nitrate uptake by ammonium in size-fractionated oceanic phytoplankton communities: Implications for new production and f-ratio estimates. J. Plankton Res. 2008, 30, 1179-1188. [CrossRef]

39. Wheeler, P.A.; Kokkinakis, S.A. Ammonium recycling limits nitrate use in the oceanic subarctic. Pacific. Limnol. Oceanogr. 1990, 35, 1267-1278. [CrossRef]

40. Holzer, H. Regulation of enzymes by enzyme-catalized chemical modification. Advanc. Enzymol. 1969, 32, $297-326$.

41. Watzer, B.; Forchhammer, K. Cyanophycin synthesis optimizes nitrogen utilization in the unicellular cyanobacterium Synechocystis sp. PCC6803. Appl. Environ. Microbiol. 2018, 84, e01298-18. [CrossRef] [PubMed]

42. Li, X.; Li, W.; Zhai, J.; Wei, H.; Wang, Q. Effect of ammonium nitrogen on microalgal growth, biochemical composition and photosynthetic performance in mixotrophic cultivation. Bioresour Technol. 2019, 273, 368-376. [CrossRef] [PubMed]

43. Huang, J.; Kankanamge, N.R.; Chow, C.; Welsh, D.T.; Li, T.; Teasdale, P.R. Removing ammonium from water and wastewater using cost-effective adsorbents: A review. J. Environ. Sci. 2018, 63, 174-197. [CrossRef] [PubMed]

44. Wang, J.; Zhou, W.; Chen, H.; Zhan, J.; He, C.; Wang, Q. Ammonium Nitrogen Tolerant Chlorella Strain Screening and Its Damaging Effects on Photosynthesis. Front. Microbiol. 2019, 9, 3250. [CrossRef]

45. Collos, Y.; Harrison, P.J. Acclimatation and toxicity of high ammonium concentrations to unicellular algae. Mar. Pollut. Bull. 2014, 80, 8-23. [CrossRef]

46. Erikson, R.J. An evaluation of mathematical models for the effects of $\mathrm{pH}$ and temperature on ammonia toxicity to aquatic organisms. Water Res. 1985, 19, 1047-1058. [CrossRef]

47. Bower, C.E.; Bidwell, J.P. Ionization of Ammonia in Seawater: Effects of Temperature, pH, and Salinity. JFRBC 1978, 35, $1012-1016$. [CrossRef]

48. Körner, S.; Das, S.K.; Veenstra, S.; Vermaat, J.E. The effect of $\mathrm{pH}$ variation at the ammonium/ammonia equilibrium in wastewater and its toxicity to Lemna gibba. Aquatic Bot. 2001, 71, 71-78. [CrossRef] 
49. Gutierrez, J.; Kwan, T.A.; Zimmerman, J.B.; Peccia, J. Ammonia inhibition in oleaginous microalgae. Algal Res. 2016, 19, $123-127$. [CrossRef]

50. Markou, G. Effect of light intensity on the degree of ammonia toxicity on PSII activity of Arthrospira platensis. Bioresour. Technol. 2016, 216, 453-461. [CrossRef]

51. Nimptsch, J.; Pflugmacher, S. Ammonia triggers the promotion of oxidative stress in the aquatic macrophyte Myriophyllum mattogrossense. Chemosphere 2007, 66, 708-714. [CrossRef] [PubMed]

52. Zengh, H.; Wu, X.; Zou, G.; Zhou, T.; Liu, Y.; Ruan, R. Cultivation of Chlorella vulgaris in manure-free piggery wastewater with high-strength ammonium for nutrients removal and biomass production: Effect of ammonium concentration, carbon/nitrogen ratio and pH. Bioresour Technol. 2019, 273, 203-211.

53. Chuka-ogwude, D.; Ogbonna, J.; Moheimani, N.R. A review on microalgal culture to treat anaerobic digestate food waste effluent. Algal Res. 2020, 47, 101841. [CrossRef]

54. Arbib, Z.; Ruiz, J.; Alvarez, P.; Garrido, C.; Barragan, J.; Perales, J.A. Chlorella stigmatophora for urban wastewater nutrient removal and $\mathrm{CO}_{2}$ abatement. Int. J. Phytoremediat. 2012, 14, 714-725. [CrossRef] [PubMed]

55. Abdel-Raouf, N.; Al-Homaidan, A.A.; Ibraheem, I.B.M. Microalgae and wastewater treatment. Saudi J. Biol. Sci. 2012, 19, 257-275. [CrossRef] [PubMed]

56. Karri, R.R.; Sahu, J.N.; Chimmiri, V. Critical review of abatement of ammonia from wastewater. J. Mol. Liq. 2018, 261, 21-31. [CrossRef]

57. Ramakrishnan, A.; Surampalli, R.Y. Performance of anaerobic hybrid reactors for the treatment of complex phenolic wastewa-ters with biogas recirculation. Bioresour. Technol. 2013, 129, 26-32. [CrossRef]

58. Wang, Z.; Xu, X.; Gong, Z.; Yang, F. Removal of COD, phenols and ammonium from Lurgi coal gasification wastewater using A2O-MBR system. J. Hazard. Mater. 2012, 235, 78-84. [CrossRef]

59. Jiang, Y.; McAdam, E.; Zhang, Y.; Heaven, S.; Banks, C.; Longhurst, P. Ammonia inhibition and toxicity in anaerobic digestion: A critical review. J. Water Process. Eng. 2019, 32, 100899. [CrossRef]

60. Kotsyurbenko, O.R.; Chin, K.J.; Glagolev, M.V.; Stubner, S.; Simankova, M.V.; Nozhevnikova, A.N.; Conrad, R. Acetoclastic and hydrogenotrophic methane production and methanogenic populations in an acidic West-Siberian peat bog. Environ. Microbiol. 2004, 6, 1159-1173. [CrossRef]

61. Ruìz-Marìn, A.; Mendoza-Espinosa, L.G.; Stephenson, T. Growth and nutrient removal in free and immobilized green algae in batch and semi-continuous cultures treating real wastewater. Bioresour Technol. 2010, 101, 58-64. [CrossRef] [PubMed]

62. Lee, C.S.; Lee, S.A.; Ko, S.R.; Oh, H.M.; Ahn, C.Y. Effects of photoperiod on nutrient removal, biomass production, and algal-bacterial population dynamics in lab-scale photobioreactors treating municipal wastewater. Water Res. 2015, 68, 680-691. [CrossRef] [PubMed]

63. Ma, B.; Wang, S.; Cao, S.; Miao, Y.; Jia, F.; Du, R.; Peng, Y. Biological nitrogen removal from sewage via anammox: Recent advances. Bioresour. Technol. 2016, 200, 981-990. [CrossRef] [PubMed]

64. Jafarinejad, S.; Park, H.; Mayton, H.; Walker, S.L.; Jiang, S.C. Concentrating ammonium in wastewater by forward osmosis using a surface modified nanofiltration membrane. Environ. Sci. Water Res. Technol. 2019, 5, 246-255. [CrossRef]

65. Cruz, H.; Luckman, P.; Seviour, T.; Verstraete, W.; Laycock, B.; Pikaar, I. Rapid removal of ammonium from domestic wastewater using polymer hydrogels. Sci. Rep. 2018, 8, 2912. [CrossRef]

66. Posadas, E.; Alcántara, C.; García-Encina, P.A.; Gouveia, L.; Guieysse, B.; Norvill, Z.; Acién, F.G.; Markou, G.; Congestri, R.; Koreiviene, J.; et al. 3-microalgae cultivation in wastewater. In Microalgae-Based Biofuels and Bioproducts; Gonzalez-Fernandez, C., Muñoz, R., Eds.; Woodhead Publishing: Lincolnshire, IL, USA, 2017; pp. 67-91.

67. García, D.; de Godos, I.; Domínguez, C.; Turiel, S.; Bolado, S.; Muñoz, R. A systematic comparison of the potential of microalgaebacteria and purple phototrophic bacteria consortia for the treatment of piggery wastewater. Bioresour Technol. 2019, $276,18-27$. [CrossRef]

68. Lee, C.; An, J.; Lee, Y.S.; Choi, K.; Kim, J.Y. Uncertainty-based concentration estimation of chlortetracycline antibiotics in swine farms and risk probability assessment for agricultural application of manure. J. Hazard. Mater. 2021, 402, 123763. [CrossRef]

69. Tchobanoglous, G.; Burton, F.L.; Stensel, H.D.; Metcalf Eddy, Inc.; Burton, F. Wastewater Engineering: Treatment and Reuse; McGraw-Hill Education: New York, NY, USA, 2003.

70. Cai, T.; Park, S.Y.; Li, Y. Nutrient recovery from wastewater streams by microalgae: Status and prospects. Renew. Sustain. Energy Rev. 2013, 19, 360-369. [CrossRef]

71. Yalei, Z.; Chunmin, Z.; Xuefei, L.; Jinpeng, L. Cultivation of Chlorella pyrenoidosa in soybean processing wastewater. Bioresour Technol. 2011, 102, 9884-9890.

72. Muylaert, K.; Beuckels, A.; Depraetere, O.; Foubert, I.; Markou, G.; Vandamme, D. Wastewater as a Source of Nutrients for Microalgae Biomass Production. In Biomass and Biofuels from Microalgae; Moheimani, N., McHenry, M., de Boer, K., Bahri, P., Eds.; Biofuel and Biorefinery Technologies; Springer: Cham, Switzerland, 2015; p. 2.

73. Raper, E.; Fisher, R.; Anderson, D.R.; Stephenson, T.; Soares, A. Nitrogen removal from coke making wastewater through a pre-denitrification activated sludge process. Sci. Total Environ. 2019, 666, 31-38. [CrossRef]

74. Reges, K.D.; Costa, A.G.; Cunha, V.T.; Portela, J.C.; Batista, R.; Mendonça, V.; Pereira, J.O.; Gurgel, G.C.; Oliveira, J.F.; Freire, F.G.; et al. Growing, Production and Quality of Thornless Cactus Irrigated With Dairies Effluent. J. Agric. Sci. 2019, 11, 175. [CrossRef] 
75. Gil-Pulido, B.; Tarpey, E.; Almeida, E.L.; Finnegan, W.; Zhan, X.; Dobson, A.; O'Leary, N. Evaluation of dairy processing wastewater biotreatment in an IASBR system: Aeration rate impacts on performance and microbial ecology. Biotechnol. Rep. 2018, 19, e00263. [CrossRef] [PubMed]

76. Cheng, W.; Chen, P.H.; Yu, R.F.; Ho, W.N. Treating ammonium-rich wastewater with sludge from water treatment plant to produce ammonium alum. Sustain. Environ. Res. 2016, 26, 63-69. [CrossRef]

77. Brown, T.; Simpson, J. Managing phosphorous inputs to urban lakes: I. Determining the trophic state of your lake. Watershed Prot. Tech. 2001, 3, 771-781.

78. Kastner, F.; Buchwald, R.; Biedermann, R. Occurrence of Aeshna viridis in marsh ditches in relation to habitat conditions (Odonata: Aeshnidae). Int. J. Odonatol. 2018, 21, 205-219. [CrossRef]

79. Ye, Y.; Ngo, H.H.; Guo, W.; Liu, Y.; Chang, S.W.; Nguyen, D.D.; Liang, H.; Wang, J. A critical review on ammonium recovery from wastewater for sustainable wastewater management. Bioresour. Technol. 2018, 268, 749-758. [CrossRef]

80. Khanzada, Z.T.; Övez, S. Growing Fresh Water Microalgae in High Ammonium Landfill Leachate. Am. AJMA 2018, 6, 40-51. [CrossRef]

81. Mayo, A.W.; Hanai, E.E. Dynamics of nitrogen transformation and removal in a pilot high rate pond. J. Water Resour. Prot. 2014, 6, 433-445. [CrossRef]

82. Fito, J.; Alemu, K. Microalgae-bacteria consortium treatment technology for municipal wastewater management. Nanotechnol. Environ. Eng. 2019, 4, 4. [CrossRef]

83. Freed, T. Wastewater industry moving toward enhanced nutrient removal standards. Water World 2007, 23, 1-3.

84. Yang, J.; Xu, M.; Zhang, X.; Hu, Q.; Sommerfeld, M.; Chen, Y. Life-cycle analysis on biodiesel production from microalgae: Water footprint and nutrients balance. Bioresour. Technol. 2011, 102, 6633. [CrossRef]

85. Judd, S.; van den Broeke, L.J.P.; Shurair, M.; Kuti, Y.; Znad, H. Algal remediation of $\mathrm{CO}_{2}$ and nutrient discharges: A review. Water Res. 2015, 87, 356-366. [CrossRef] [PubMed]

86. Markou, G.; Depraetere, O.; Muylaert, K. Effect of ammonia on the photosynthetic activity of Arthrospira and Chlorella: A study on chlorophyll fluorescence and electron transport. Algal Res. 2016, 16, 449-457. [CrossRef]

87. Vargas, G.; Donoso-Bravo, A.; Vergara, C.; Ruiz-Filippi, G. Assessment of microalgae and nitrifiers activity in a consortium in a continuous operation and the effect of oxygen depletion. Electron. J. Biotechnol. 2016, 23, 63-68. [CrossRef]

88. Praveen, P.; Loh, K. Nutrient removal in an algal membrane photobioreactor: Effects of wastewater composition and light/dark cycle. Appl. Microbiol. Biotechnol. 2019, 103, 3571-3580. [CrossRef]

89. De-Bashan, L.E.; Trejo, A.; Huss, V.A.R.; Hernandez, J.-P.; Bashan, Y. Chlorella sorokiniana UTEX 2805, a heat and intense, sunlight-tolerant microalga with potential for removing ammonium from wastewater. Bioresour Technol. 2008, 99, 4980-4989.

90. Kobayashi, N.; Noel, E.A.; Barnes, A.; Watson, A.; Rosenberg, J.N.; Erickson, G.; Oyler, G.A. Characterization of three Chlorella sorokiniana strains in anaerobic digested effluent from cattle manure. Bioresour Technol. 2013, 150, 377-386. [CrossRef]

91. Hernández, D.; Riaño, B.; Coca, M.; García-González, M.C. Treatment of agro-industrial wastewater using microalgae-bacteria consortium combined with anaerobic digestion of the produced biomass. Bioresour Technol. 2013, 135, 598-603. [CrossRef]

92. Moondra, N.; Jariwala, N.D.; Christian, R.A. Sustainable treatment of domestic wastewater through microalgae. Int. J. Phytoremediat. 2020, 22, 1480-1486. [CrossRef]

93. Sydney, E.B.; da Silva, T.E.; Tokarski, A.; Novak, A.C.; de Carvalho, J.C.; Woiciecohwski, A.L.; Larroche, C.; Soccol, C.R. Screening of microalgae with potential for biodiesel production and nutrient removal from treated domestic sewage. Appl. Energy 2011, 88, 3291-3294. [CrossRef]

94. Kang, J.; Wen, Z. Use of microalgae for mitigating ammonia and $\mathrm{CO}_{2}$ emissions from animal production operations-Evaluation of gas removal efficiency and algal biomass composition. Algal Res. 2015, 11, 204-210. [CrossRef]

95. Uggetti, E.; Sialve, E.; Latrille, E.; Steyer, J.P. Anaerobic digestate as substrate for microalgae culture: The role of ammonium concentration on the microalgae productivity. Bioresour Technol. 2014, 152, 437-443. [CrossRef] [PubMed]

96. Pham, T.L.; Bui, M.H. Removal of Nutrients from Fertilizer Plant Wastewater Using Scenedesmus sp.: Formation of Bioflocculation and Enhancement of Removal Efficiency. J. Chem. 2020, 2020, 9. [CrossRef]

97. Henkanatte-Gedera, S.M.; Selvaratnam, T.; Karbakhshravari, M.; Myint, M.; Nirmalakhandan, N.; Van Voorhies, W.; Lammers, P.J Removal of dissolved organic carbon and nutrients from urban wastewaters by Galdieria sulphuraria: Laboratory to field scale demonstration. Algal Res. 2017, 24, 450-456. [CrossRef]

98. Selvaratnam, T.; Pegallapati, A.K.; Montelya, F.; Rodriguez, G.; Nirmalakhandan, N.; Van Voorhies, W.; Lammers, P.J. Evaluation of a thermo-tolerant acidophilic alga, Galdieria sulphuraria, for nutrient removal from urban wastewaters. Bioresour Technol. 2014, 156, 395-399. [CrossRef] [PubMed]

99. Sloth, J.K.; Jensen, H.C.; Pleissner, D.; Eriksen, N.T. Growth and phycocyanin synthesis in the heterotrophic microalga Galdieria sulphuraria on substrates made of food waste from restaurants and bakeries. Bioresour Technol. 2017, 238, 296-305. [CrossRef]

100. Arashiro, L.T.; Boto-Ordóñez, M.; Van Hulle, S.W.H.; Ferrer, I.; Garfí, M.; Rousseau, D.P.L. Natural pigments from microalgae grown in industrial wastewater. Bioresour Technol. 2020, 303, 122894. [CrossRef]

101. Hernández, D.; Riaño, B.; Coca, M.; Solana, M.; Bertucco, A.; García-González, M.C. Microalgae cultivation in high rate algal ponds using slaughterhouse wastewater for biofuel applications. Chem. Eng. J. 2016, 285, 449-458. [CrossRef]

102. Winayu, B.N.R.; Lai, K.T.; Hsueh, H.T.; Chu, H. Production of phycobiliprotein and carotenoid by efficient extraction from Thermosynechococcus sp. CL-1 cultivation in swine wastewater. Bioresour Technol. 2021, 319, 124125. [CrossRef] 
103. Rinna, F.; Buono, S.; Cabanelas, I.T.D.; Nascimento, I.A.; Sansone, G.; Barone, C.M.A. Wastewater treatment by microalgae can generate high quality biodiesel feedstock. J. Water Process. Eng. 2017, 18, 144-149. [CrossRef]

104. Kolmert, A.; Johnson, D.B. Remediation of acidic waste waters using immobilised, acidophilic sulfate-reducing bacteria. J. Chem. Technol. Biotechnol. 2001, 76, 836-843. [CrossRef]

105. Goyal, A.; Srivastava, V.C. Treatment of highly acidic wastewater containing high energetic compounds using dimensionally stable anode. Chem. Engin. J. 2017, 325, 289-299. [CrossRef]

106. Hirooka, S.; Miyagishima, S. Cultivation of Acidophilic Algae Galdieria sulphuraria and Pseudochlorella sp. YKT1 in Media Derived from Acidic Hot Springs. Front. Microbiol. 2016, 7, 2022. [CrossRef] [PubMed]

107. Nancucheo, I.; Johnson, D.B. Acidophilic algae isolated from mine-impacted environments and their roles in sustaining heterotrophic acidophiles. Front. Microbial. 2012, 3, 325. [CrossRef] [PubMed]

108. Carfagna, S.; Landi, V.; Coraggio, F.; Salbitani, G.; Vona, V.; Pinto, G.; Pollio, A.; Ciniglia, C. Different characteristics of C-phycocyanin (C-PC) in two strains of the extremophilic Galdieria phlegrea. Algal Res. 2018, 31, 406-412. [CrossRef]

109. Salbitani, G.; Cipolletta, S.; Vona, V.; Di Martino, C.; Carfagna, S. Heterotrophic Cultures of Galdieria phlegrea Shift to Autotrophy in the Presence or Absence of Glycerol. J. Plant. Growth Regul. 2020. [CrossRef]

110. Barone, R.; De Napoli, L.; Mayol, L.; Paolucci, M.; Volpe, M.G.; D’Elia, L.; Pollio, A.; Guida, M.; Gambino, E.; Carraturo, F.; et al. Autotrophic and Heterotrophic Growth Conditions Modify Biomolecole Production in the Microalga Galdieria sulphuraria (Cyanidiophyceae, Rhodophyta). Mar. Drugs 2020, 18, 169. [CrossRef]

111. Bugajski, P.; Kurek, K.; Jóźwiakowski, K. Effect of wastewater temperature and concentration of organic compounds on the efficiency of ammonium nitrogen removal in a household treatment plant servicing a school building. Arch. Environ. Prot. 2019, $45,31-37$.

112. Alisawi, H.A.O. Performance of wastewater treatment during variable temperature. Appl. Water Sci. 2020, 10, 89. [CrossRef]

113. Varshney, P.; Mikulic, P.; Vonshak, A.; Beardall, J.; Wangikar, P.P. Extremophilic micro-algae and their potential contribution in biotechnology. Bioresour. Technol. 2015, 184, 363-372. [CrossRef]

114. Von Sperling, M. Wastewater Characteristics, Treatment and Disposal; IWA Publishing: London, UK, 2007.

115. Langenhoff, A.A.M.; Stuckey, D.C. Treatment of dilute wastewater using an anaerobic baffled reactor: Effect of low temperature. Water Res. 2000, 34, 3867-3875. [CrossRef]

116. Lettinga, G.; Rebac, S.; Zeeman, G. Challenge of psychrophilic anaerobic wastewater treatment. Trends Biotechnol. 2001, 19, 363-370. [CrossRef]

117. Vona, V.; Di Martino Rigano, V.; Andreoli, C.; Lobosco, O.; Caiazzo, M.; Martello, A.; Carfagna, S.; Salbitani, G.; Rigano, C. Comparative analysis of photosynthetic and respiratory parameters in the psychrophilic unicellular green alga Koliella antarctica, cultured in indoor and outdoor photo-bioreactors. Physiol. Mol. Biol. Plants 2018, 24, 1139-1146. [CrossRef] [PubMed]

118. Andreoli, C.; Lokhrost, G.M.; Mani, A.M.; Scarabel, L.; Moro, I.; La Rocca, N.; Tognetto, L. Koliella antarctica sp. nov. (Klebsormidiales) a new marine green microalga from the Ross Sea. Algological Studies Archiv für Hydrobiologie 1998, 125, 1-8.

119. Fogliano, V.; Andreoli, C.; Martello, A.; Caiazzo, M.; Lobosco, O.; Formisano, F.; Carlino, P.A.; Meca, G.; Graziani, G.; Di Martino Rigano, V.; et al. Functional ingredients produced by culture of Koliella antartica. Aquaculture 2010, 299, 115-120. [CrossRef]

120. Alavi, S.; Rafieyan, S.; Yavari-Bafghi, M.; Amoozegar, M.A. Extremophiles: A Powerful Choice for Bioremediation of Toxic Oxyanions. In Microbial Bioremediation E Biodegradation; Shah, M., Ed.; Springer: Singapore, 2020. [CrossRef]

121. Yu, Z.; Song, M.; Pei, H.; Han, F.; Jiang, L.; Hou, Q. The growth characteristics and biodiesel production of ten algae strains cultivated in anaerobically digested effluent from kitchen waste. Alga Res. 2017, 24, 265-275. [CrossRef]

122. Sharma, J.; Kumar, V.; Kumar, S.S.; Malyan, S.K.; Mathimani, T.; Bishnoi, N.R.; Pugazhendhi, A. Microalgal consortia for municipal wastewater treatment-Lipid augmentation and fatty acid profiling for biodiesel production. J. Photochem. Photobiol. B 2020, 202, 111638. [CrossRef]

123. Yang, J.; Li, X.; Hu, H.Y.; Zhang, X.; Yu, Y.; Chen, Y.S. Growth and lipid accumulation properties of a freshwater microalga, Chlorella ellipsoidea Yj1, in domestic secondary effluents. Appl. Energy 2011, 88, 3295-3299. [CrossRef]

124. Li, X.; Hu, H.Y.; Yang, J. Lipid accumulation and nutrient removal properties of a newly isolated freshwater microalga, Scenedesmus sp. LX1, growing in secondary effluent. New Biotechnol. 2010, 27, 59-63.

125. Meng, T.K.; Kassim, M.A.; Cheirsilp, B. Chapter 4-Mixotrophic cultivation: Biomass and biochemical biosynthesis for biofuel production. In Microalgae Cultivation for Biofuels Production; Yousuf, A., Ed.; Academic Press: Cambridge, MA, USA, 2020; pp. 51-67.

126. Rodrigues, D.B.; Flores, É.M.M.; Barin, J.S.; Mercadante, A.Z.; Jacob-Lopes, E.; Zepka, L.Q. Production of carotenoids from microalgae cultivated using agroindustrial wastes. Food Res. Int. 2014, 65, 144-148. [CrossRef] 